\title{
Rhizobacterial Communities and Red Pepper (Capsicum annum) Yield under Different Cropping Systems
}

\author{
Byung Kwon Jung ${ }^{1,2 \dagger}$, Sang-Dal Kim ${ }^{1 \dagger}$, Abdur Rahim Khan ${ }^{2}$, Jong-Hui Lim ${ }^{1}$, Chang-Hwan An ${ }^{1}$, Yo-Hwan Kim ${ }^{1}$, Jin \\ Ha Song ${ }^{1}$, Sung-Jun Hong ${ }^{2}$ and Jae-Ho Shin ${ }^{2 *}$ \\ ${ }^{1}$ Department of Applied Microbiology and Biotechnology, School of Biotechnology, Yeungnam University, Gyeongsan, 712 - \\ 729, Republic of Korea \\ ${ }^{2}$ School of Applied Biosciences, College of Agriculture and Life Sciences, Kyungpook National University, Daegu, 702-701, \\ Republic of Korea \\ *For correspondence: jhshin@knu.ac.kr \\ ${ }^{\dagger}$ These authors contributed equally to this work
}

\begin{abstract}
The intensive cropping of red pepper (Capsicum annuиm L.) negatively affects the soil environment and reduces crop yield. The red pepper plant's rhizospheric bacterial communities under different cropping methods (intensive cropping or crop rotation) were investigated over three years (2010 to 2012). The red pepper yield and bacterial communities were also investigated under agrochemical treatment or microbial agent treatment against Phytophthora blight disease. Pyrosequencing of 16S rRNA gene amplicon libraries were constructed to characterize the bacterial communities. Bacterial richness and red pepper yield increased $65 \%$ and $55 \%$, respectively under the crop rotation method combined with the microbial agent treatment, whereas the intensive cropping method with the agrochemical treatment resulted in low richness and diversity. The dominant bacterial phylogenetic phyla present were Acidobacteria, Proteobacteria, Gemmatimonadetes, Chloroflexi, and Planctomycetes, ranging from $5 \%$ to $38 \%$ of the sequences. In conclusion, crop rotation and microbial agent has a synergistic positive effect not only on rhizobacterial diversity, but also on red pepper yield. (C) 2015 Friends Science Publishers
\end{abstract}

Keywords: Crop rotation; Intensive cropping; Pyrosequencing; Red pepper; Rhizobacterial diversity

\section{Introduction}

The red pepper (Capsicum annum L.) is widely used in a variety of commercial food products as powder, paste, and pickle in Korea and worldwide, and accounted for approximately $1 \%$ of the total Korean agricultural field acreage in 2006 (Kim et al., 2006; Chung et al., 2008). Among frequently occurring plant diseases, the most common, and the most devastating disease affecting the red pepper plant is Phytophthora blight, caused by Phytophthora capsici. The reduction in yield caused by Phytophthora blight infection has been estimated to account for $30-80 \%$ of global annual red pepper production (Lee $e t$ al., 2008). The application of agrochemicals and crop rotation are being practiced to control this soil-borne disease. However, chemical treatments have provided promising results in controlling the disease but their phytotoxicity and chemical residues may cause a serious risk to the environment (Rajkumar et al., 2005). This problem has attracted the interest of agronomists in antagonistic microbes, which might be used for the biological control of the pathogen in the field (Berg et al., 2000; Joo, 2005; Costa et al., 2006; Lee et al., 2008). Recently, biological control has emerged as an alternative method to control such soilborne plant diseases. In this regard, several rhizobacteria have been used as biological agents to control phytopathogens (Jeun et al., 2004).

The rhizosphere, which is defined as the part of soil which is adjacent to, and affected by plant root (Sørensen, 1997), has frequently been used as a model environment for the isolation of potential biological control strains (Raaijmakers et al., 1997; Picard et al., 2000; Costa et al., 2006). Plant growth-promoting rhizobacteria (PGPR) are diverse, root-associated bacteria that induce plant growth promotion and disease control. Many PGPR are known to enhance plant growth, either by increasing access to phosphate and iron, or by influencing plant metabolism through the production of phytohormones, such as auxin, gibberellin, and cytokinins (Kloepper et al., 2007). Additionally, the natural role of PGPR in maintaining soil health is more important than in traditional agriculture, where the frequent use of agrochemicals minimizes their significance (Yildirim et al., 2010). The potential role of PGPR in conferring resistance against water stress in tomatoes and peppers has been investigated (Mayak et al., 2004). Many species of Pseudomonas and Bacillus are 
highly efficient at host root colonization, as well as the production of growth metabolites that result in improved strategic crop yields (Khalid et al., 2004).

In addition to such approaches, crop rotation is an alternative strategy to intensive cropping that maintains soil nutrient levels and crop yields. Xuan et al. (2012) showed that soil bacterial community structures are influenced by crop rotation systems that increase rice yield (Xuan et al., 2012). One of the utmost significant influence of crops rotation on the soil environment is on soil microbial communities (Larkin et al., 2006). Higher diversity of bacterial population was detected in soil under a cottonwheat-corn rotation compared with a cotton-cotton-cotton rotation (Acosta-Martínez et al., 2008). Another beneficial effect of crop rotation is disease prevention, which in a sugar beet pathogenic system has been related to an increased abundance of specific bacterial groups, including Proteobacteria, Firmicutes, and Actinobacteria (Mendes et al., 2011). However, the effects of crop rotation with microbial agents on the diversity of soil microbial community are not fully exploited.

Hence, composition as well as the diversity of rhizospheric soil bacterial communities under different red pepper cropping systems with agrochemical treatment or microbial agent treatment was compared using 454pyrosequencing technology.

\section{Materials and Methods}

\section{Microbial Agent and Agrochemical}

The microbial consortium applied in this experiment comprised of three strains: Bacillus licheniformis K11, Bacillus subtilis AH18, and Pseudomonas fluorescens 2112, which are PGPR and exhibit antagonistic activity against the Phytophthora blight disease (Lim et al., 2009; Kim et al., 2012). An agrochemical Ridomil Gold ${ }^{\circledR}$ granule (Dongbu Chemical, Korea) that contained $4 \%$ (w/w) copper oxychloride metalaxyl-M as the fungicidal agent was used for the comparative part of the microbial agent.

\section{Experimental Design and Soil Sampling Procedure}

A red pepper cultivation field $(23 \mathrm{~m} \times 33 \mathrm{~m})$ was prepared in the campus of Yeungnam University, Gyeongsan, Gyeongsangbukdo, Korea (3549'54"N, 128 45'31"E). The chemical properties of the field's rhizospheric soil (depth of 0-30 cm) were measured based on the protocols of the National Institute of Agricultural Science and Technology, and the methods of Ahmad et al. (2012). Soil pH was measured electrometrically ( $\mathrm{pH}$ meter, Seven Easy, Switzerland) using 1:5 (w/v) distilled water extracts. Exchangeable cations $(\mathrm{K}, \mathrm{Ca}$, and $\mathrm{Mg}$ ), extracted with neutral $1 \mathrm{M}$ ammonium acetate were detected through an inductively coupled plasma optical emission spectrometer (ICP-OES, OPTIMA 7300 DV, USA). The chlorostannous acid method was used to determine the available phosphorous (P), in association with a ultraviolet spectrophotometer (UV-1800, Shimadzu, Japan). Soil organic matter $(\mathrm{OM})$ content was calculated from the total carbon contents by applying a traditional conversion factor of 1.724 .

The field experiments were consisted of three treatments (water only, microbial agent, and agrochemical) in a randomized block design manner. Each plot $(0.6 \mathrm{~m} \times 17$ m) contained 25 plants. Red pepper cultivation, from seeding to harvest, was conducted three times over three years (2010-2012). For the crop rotation samples (pepperbean-pepper), kidney bean plants (Phaseolus vulgaris var. humilis Alef.) were used in the second year (2011). Only red pepper was planted for the intensive cropping samples (pepper-pepper-pepper). Red pepper seeds were purchased from Syngenta Inc. (Seoul, Korea), and kidney beans were purchased from Aramseed Co. (Seoul, Korea). The seeds were planted in a seedbed, and early plants with four leaves were selected and transplanted into the main field plot in April.

The microbial agent and agrochemical treatments were as follows: one week after transplant, a mixture of the three bacterial culture pellets was suspended in water and $100 \mathrm{~L}$

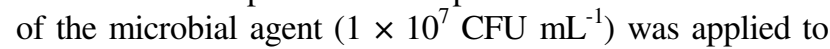
each plot. For the agrochemical treatment, $50 \mathrm{~g}$ of Ridomil Gold $^{\circledR}$ was suspended in $100 \mathrm{~L}$ of water and applied to each plot. The same volume of water was applied to the controls. After six months each plant was harvested, and productivity was evaluated as the dry weight of fruit or seeds per plant. The rhizospheric soil samples were collected from six randomly selected plants from each plot. The soil samples were then used for DNA extraction.

\section{Soil DNA Extraction and Purification}

Soil DNA was extracted following the method as described by Smith and Tiedje (1992), with slight modifications. Each soil sample $(10 \mathrm{~g})$ was suspended in $13.5 \mathrm{~mL}$ of DNA extraction buffer (0.1 m $M$ Tris-Cl [pH 8.0], 0.1 $M$ EDTA [pH 8.0], 1\% CTAB, $0.5 M$ phosphate buffer, and $1.5 M$ $\mathrm{NaCl}$ ) and mixed thoroughly. After adding $50 \mu \mathrm{L}$ of proteinase $\mathrm{K}\left(20 \mathrm{mg} \mathrm{mL}^{-1}\right)$, the sample was incubated for 1 $\mathrm{h}$ at $37^{\circ} \mathrm{C}$. Subsequently, the sample was frozen at $-70^{\circ} \mathrm{C}$ for $1 \mathrm{~h}$ and incubated at $65^{\circ} \mathrm{C}$ for $2 \mathrm{~h}$, after adding $3 \mathrm{~mL}$ of $10 \%$ SDS solution. The mixture was then centrifuged for $10 \mathrm{~min}$ at $3,000 \times g$ to remove insoluble residues. DNA was precipitated by adding $8 \mathrm{~mL}$ of $30 \%$ (w/v) PEG 8,000 in 1.6 $M \mathrm{NaCl}$ solution, and incubated at $25^{\circ} \mathrm{C}$ for $2 \mathrm{~h}$. After centrifugation, the DNA pellet was re-suspended in $1 \mathrm{~mL}$ of TE buffer (10 $\mathrm{m} M$ Tris-Cl, $1 \mathrm{~m} M$ EDTA, $8.0 \mathrm{pH}$ ). The crude DNA extract was purified using an equal volume of phenol:chloroform:iso-amyl alcohol (25:24:1), and once with chloroform:iso-amyl alcohol (24:1). DNA was precipitated by adding $0.6 \mathrm{vol}$. of isopropanol and pelleted at $12,000 \times g$ for $15 \mathrm{~min}$. The DNA pellet was washed with $70 \%$ ethanol, air-dried, and dissolved in $100 \mu \mathrm{L}$ of TE buffer. 
To remove residual humic acid, the DNA sample was loaded on $1 \%(\mathrm{w} / \mathrm{v})$ low-melting-point agarose gel and run, and was recovered using $\beta$-agarase and ethanol precipitation.

\section{Pyrosequencing of 16S rRNA Gene Amplicons}

Purified soil DNA (10 ng) was used for amplification in 50 $\mu \mathrm{L}$ of PCR reaction, using Pfu polymerase (Takara Bio Inc., Shiga, Japan). In order to amplify the region V1 to V3 of the $16 \mathrm{~S}$ rRNA gene, the fusion-16S-27F (5'-CCT ATC CCC TGT GTG CCT TGG CAG TCT CAG ACG AGT TTG ATC MTG GCT CAG, where $\mathrm{M}$ is $\mathrm{A}$ or $\mathrm{C}$ ) and the fusion16S-518R (5'-CCA TCT CAT CCC TGC GTG TCT CCG ACT CAG ATC AGC ACA CWT TACC GCG GCT GCT $\mathrm{GG}$, where $\mathrm{W}$ is $\mathrm{A}$ or $\mathrm{T}$ ) were used. PCR amplification were performed using the following conditions: pre-denaturation at $94^{\circ} \mathrm{C}$ for $5 \mathrm{~min}$, followed by 30 cycles of $30 \mathrm{~s}$ denaturation at $94^{\circ} \mathrm{C}$, annealing step at $55^{\circ} \mathrm{C}$ for $45 \mathrm{~s}$, extension at $72^{\circ} \mathrm{C}$ for $90 \mathrm{~s}$ and final extension at $72^{\circ} \mathrm{C}$ for 5 min. PCR products were pooled and $1 \mu \mathrm{g}$ was used for the sequencing of each sample. Sequencing and basic analyses were carried out by Chunlab Inc. (Seoul, Korea) according to the methodology given by Chun et al. (2010) using the Roche/454 GS-FLX Titanium sequencing platform (Roche, Switzerland).

\section{Processing of Pyrosequencing Data}

The sequencing raw reads were arranged for each sample by means of unique barcodes. After that, the barcode, linker, and primers were eliminated from either ends of the raw pyrosequencing reads. After that, the sequences were subjected to a filtering process through, which only those reads were selected for the final bioinformatics analyses which contained 0 to 1 ambiguous base cells $(\mathrm{Ns})$ with a base pairs size 300 or more. Furthermore, those PCR amplicons which had no homology with the 16S rRNA gene database in a BLASTN search (expectation value of $>10^{-5}$ ) were also deleted from the succeeding analyses. Chimeras were analyzed by pattern differences of BLASTN-based sequence similarity between the first and second half of target sequence. When the first and second halves were differentially identified at the bacterial order level, the chimeric sequences were counted and removed. The taxonomic assignment for each sequencing read was confirmed through the EzTaxon-e database (http://www.ezbiocloud.net/) (Chun et al., 2007), which has $16 \mathrm{~S}$ rRNA sequences of majority of type strains of representative species level phylotypes and validly published names, of either uncultured or cultured entries in the GenBank database, with a taxonomic hierarchy from phylum to species (Chun et al., 2007).

\section{Statistical Analyses}

Ribosomal Database Project (RDP) release 10 pyrosequencing pipeline (Cole et al., 2009) was used to calculate the diversity and species richness. Assigning a sequence to same group was done by using the cutoff value greater than or equal to $97 \%$ similarity. The data were presented as means \pm SD. Significant differences were verified via Duncan's multiple range tests at a confidence level of 95\%. Further Statistical analyses were accomplished by using SPSS software version 13.0 (SPSS, Inc., USA).

\section{Results}

\section{Characterization of the Soil}

The initial soil chemical properties of the experimental field are presented in Table 1. The soil was sandy loam in texture, and the $\mathrm{pH}$ (7.7) was slightly alkaline compared to the typical $\mathrm{pH}$ of cultivated upland soils in Korea (Jo et al., 2004). The soil organic matter $\left(17.83 \mathrm{~g} \mathrm{~kg}^{-1}\right)$ and available phosphorous $\left(222.5 \mathrm{mg} \mathrm{kg}^{-1}\right)$ content were slightly lower than optimal values for Korean upland soils $\left(20-30 \mathrm{~g} \mathrm{~kg}^{-1}\right.$ for the soil organic matter and $300-500 \mathrm{mg} \mathrm{kg}^{-1}$ for the available phosphorous). Exchangeable $\mathrm{Ca}\left(13.83 \mathrm{cmol} \mathrm{kg}^{-1}\right)$ and $\mathrm{Mg}\left(2.73 \mathrm{cmol} \mathrm{kg}^{-1}\right)$ levels were almost two to three folds higher than those of normal levels $(5.0$ and $1.5 \mathrm{cmol}$ $\mathrm{kg}^{-1}$, respectively) in Korean upland soils. However, exchangeable $\mathrm{K}$ levels $\left(0.63 \mathrm{cmol} \mathrm{kg}^{-1}\right)$ were close to the normal range $\left(0.50-0.60 \mathrm{cmol} \mathrm{kg}^{-1}\right)$. The levels of all the chemicals, including organic matter, inorganic phosphate, and exchangeable cations, presented no significant problems for the plant cultivation experiments.

\section{Red Pepper Yield under Different Cropping Methods and Agents}

As mentioned above in materials and methods, the two antifungal agents (a microbial agent and an agrochemical agent) were applied during the three years of pepper cultivation. A treatment without an agent (water only) was included as a control. The total dry weight of the pepper fruit per plant was measured after harvesting on the $12^{\text {th }}$ October 2012, the third year of intensive cropping (pepperpepper-pepper) and crop rotation (pepper-bean-pepper). Fig. 1 shows that the pepper plants with a microbial agent produced an average of $114.0 \mathrm{~g}$ (intensive cropping field) and $117.7 \mathrm{~g}$ (crop rotation field) of fruit as dry weight per plant, whereas all of the pepper plants from the agrochemical agent- and water-only- treated fields produced less than $100 \mathrm{~g}$ of fruit per plant. There was an insignificant difference in fruit yield between either the water-treated or agrochemical agent-treated plants in either crop method.

\section{Bacterial Community Structures}

The taxonomic distribution of the bacterial 16S rRNA gene sequences in the soil samples are shown in Fig. 2. 
Table 1: Initial soil chemical properties in the red pepper experimental field in 2010

\begin{tabular}{|c|c|c|c|c|c|}
\hline \multirow{2}{*}{$\mathrm{pH}\left(1: 5 \mathrm{H}_{2} \mathrm{O}\right)$} & \multirow{2}{*}{ Organic matter $\left(\mathrm{g} \mathrm{kg}^{-1}\right)$} & \multirow{2}{*}{ Av. $\mathrm{P}_{2} \mathrm{O}_{5}\left(\mathrm{mg} \mathrm{kg}^{-1}\right)$} & \multicolumn{3}{|c|}{ Exchangeable cations } \\
\hline & & & Exch. $-\mathrm{K}\left(\mathrm{cmol} \mathrm{kg}^{-1}\right)$ & Exch. $-\mathrm{Ca}\left(\mathrm{cmol} \mathrm{kg}^{-1}\right)$ & Exch. $-\mathrm{Mg}\left(\mathrm{cmol} \mathrm{kg}^{-1}\right)$ \\
\hline $7.7 \pm 0.02$ & $17.83 \pm 1.1$ & $222.5 \pm 25$ & $0.63 \pm 0.066$ & $13.83 \pm 0.08$ & $2.73 \pm 0.03$ \\
\hline
\end{tabular}

All values are means $(\mathrm{n}=6)$ of six independent experiments

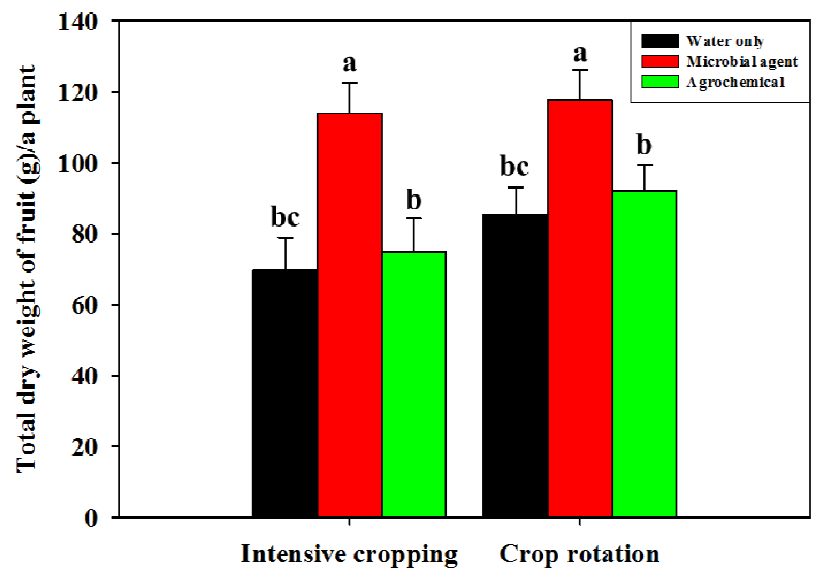

Fig. 1: The red pepper yield (grams per red pepper plant) from two cropping systems and three treatments at harvest in October 2012. Evaluation of the dry weight yields of red pepper fruit were measured six times, and yields were divided by the number of red pepper plants. Values are expressed as the mean $\pm S D(n=6)$ of six independent experiments. Different letters on different bars indicate a significant difference (One-way ANOVA and Duncan post-hoc test; $\mathrm{p}<0.05)$

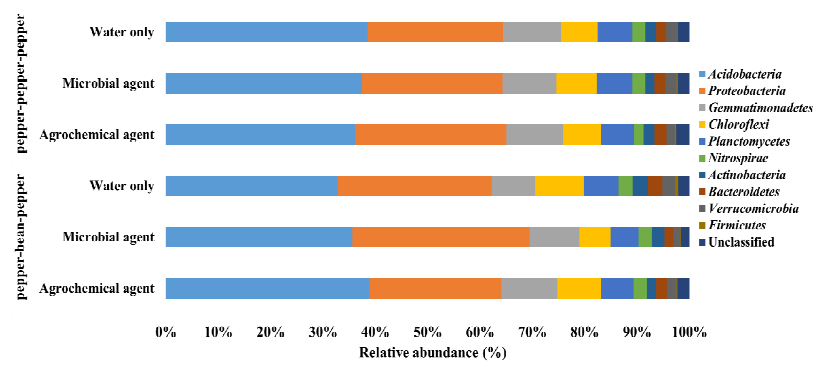

Fig. 2: The proportional distribution of classified phyla levels from three treatments with different cropping systems. Shown are the percentages of the phylogenetically classified sequences. The group "Unclassified" represents sequences which match EzTaxon database entries that cannot be assigned to a taxonomic group

Almost $95 \%$ of the soil bacteria belonged to the nine phyla which are most frequently found in soil (Actinobacteria, Acidobacteria, Bacteroidetes, Chloroflexi Proteobacteria, Planctomycetes, Gemmatimonadetes, Verrucomicrobia and Firmicutes). Acidobacteria was the most dominant phylum in all the treatments, representing $33-38 \%$ of the total bacterial community. The second most dominant phylum was Proteobacteria, which ranged from $25-33 \%$.
Among the other phyla, the Gemmatimonadetes and Chloroflexi represented $8-11 \%$ and 5-9\% of the sequences in all the samples, respectively. In the crop rotation soil (pepper-bean-pepper), Nitrospira presented by more than $2.5 \%$ of the sequences. In the intensive cropping soil, nearly $2 \%$ of the 16S rRNA gene sequences was from the Bacteroidetes. Those sequences which could not be allotted to any phyla were pooled as "Unclassified", which represented approximately $1.7-2.5 \%$ of the sequences for each sample (Fig. 2).

\section{Bacterial Diversity and Richness}

To estimate bacterial richness, a Cluster Database at High Identity with Tolerance (CD-HIT) was used. The results confirmed that the crop rotation method (pepper-beanpepper) exhibited more bacterial operational taxonomic units (OTUs) at a 97\% sequence identity (Table 2). For example, 2,384 bacterial OTUs were measured from the microbial agent-treated crop rotation field sample, but only 2,001 OTUs were found from the same treatment but intensive cropping field sample. Field samples treated with a microbial agent from both cultivating methods had more OTUs than the agrochemical agent-treated or water-treated samples.

Abundance-based Coverage Estimation (ACE), the Chao1 estimator, and the Shannon-Weaver index were used to estimate bacterial species diversity. With all the estimations, the microbial agent-treated soil sample with the crop rotation method exhibited the highest diversity. Moreover, soils under the crop rotation method generally had higher bacterial diversities than those under the intensive cropping method.

\section{Proportional Abundances of Major Classifiable Bacteria ( $>10$ OTU) at the Species Level}

A thorough investigation at the species level showed an enrichment trend of beneficial bacterial groups, such as nitrogen-fixing bacteria. Fig. 3 shows that the number of Rhizobium leguminosarum, $R$. etli, and $R$. grahamii in the crop rotation field treated with a microbial agent (green circles) was significantly higher than that in the intensive cropping soils with agrochemical agent treatment (red circles), which indicates a high level of nitrogen (as ammonium) in this treatment. The most abundant classifiable species in the crop rotation samples were Cupriavidus necator ( $\beta$-proteobacteria). However, analysis of the classifiable species in the intensive cropping field revealed that the most abundant was Pseudomonas resinovorans ( $\gamma$-proteobacteria), which was placed in the 
Table 2: Richness and diversity estimates of the bacterial 16S rRNA amplicon libraries constructed from the rhizosphere soil from a red pepper field

\begin{tabular}{|c|c|c|c|c|c|}
\hline \multirow[t]{2}{*}{ Treatments* } & & \multicolumn{4}{|c|}{ Richness and diversity estimates $^{a}$} \\
\hline & & Richness $^{b}$ & $\mathrm{ACE}^{c}$ & $\mathrm{Chaol}^{d}$ & Shannon $^{e}$ \\
\hline \multirow[b]{2}{*}{ Pepper-Pepper-Pepper } & Water only & 1,618 & 6,184 & 3,774 & 6.71 \\
\hline & Microbial agent & 2,001 & 7,113 & 4,608 & 6.88 \\
\hline \multirow{3}{*}{ Pepper-Bean-Pepper } & Water only & 1,653 & 6,722 & 4,064 & 6.86 \\
\hline & Microbial agent & 2,384 & 9,588 & 5,923 & 6.96 \\
\hline & Agrochemical agent & 1,612 & 6,315 & 3,768 & 6.67 \\
\hline
\end{tabular}

${ }^{a}$ The estimates were calculated using CD-HIT based on $>97 \%$ identify cutoff

${ }^{b}$ Richness is expressed as the number of observed OTUs

${ }^{c}$ The ACE incorporates data from all species with fewer than ten individuals, rather than just singletons and doubletons

${ }^{d}$ The Chaol is a nonparametric estimator adapted from mark-release-recapture (MRR) statistics

${ }^{e}$ The Shannon-Weaver index represents the species diversity of a community; the higher the value, the higher the diversity

Pseudomonas aeruginosa group. Some other beneficial species were also detected from the rhizospheres of the crop rotation soil. Within the Actinobacteria phylum, we found more species of Streptomyces genus in the crop rotation samples (green and purple circles) than in the intensive cropping soils (blue and red circles). Streptomyces bottropensis, belonging to the Actinobacteria phylum, was found in microbial agent-treated soils. It represented 10 OTUs in the microbial agent-treated soils, from both the intensive cropping and the crop rotation fields.

\section{Discussion}

Next generation sequencing technology can analyze a larger number of microbial sequences than traditional sequencing technology, and provides a more specific comparison of rhizospheric soil microbial communities and diversity (Wommack et al., 2008; Teixeira et al., 2010). In this study, bacterial species richness and diversity in the rhizosphere was much higher than previously reported (Qiu et al., 2012; Peiffer et al., 2013).

Both red pepper production and the soil bacterial diversity in the crop rotation field with the microbial agent treatment significantly increased in our study. This result is consistent with results from several other studies, demonstrating that plant type and biological agent have specific effects on soil bacterial community composition in the rhizosphere (Qiu et al., 2012; Xuan et al., 2012). The dominant phyla in all the soil samples were Proteobacteria, Actinobacteria, Acidobacteria, Chloroflexi, Verrucomicrobia, Bacteroidetes, Planctomycetes, Gemmatimonadetes and Firmicutes, which accounted for an average of $95 \%$ of all the sequences. These phyla are present in both agricultural and nonagricultural soils (Kim et al., 2007; Lee et al., 2011).

Red pepper production yield was lowest in the intensive cropping with agrochemical agent treatment. Furthermore, bacterial species richness and diversity (as estimated using ACE, Chaol, and the Shannon-Weaver index) in the intensive cropping and/or agrochemical agent treatment were generally lower than that in the crop rotation

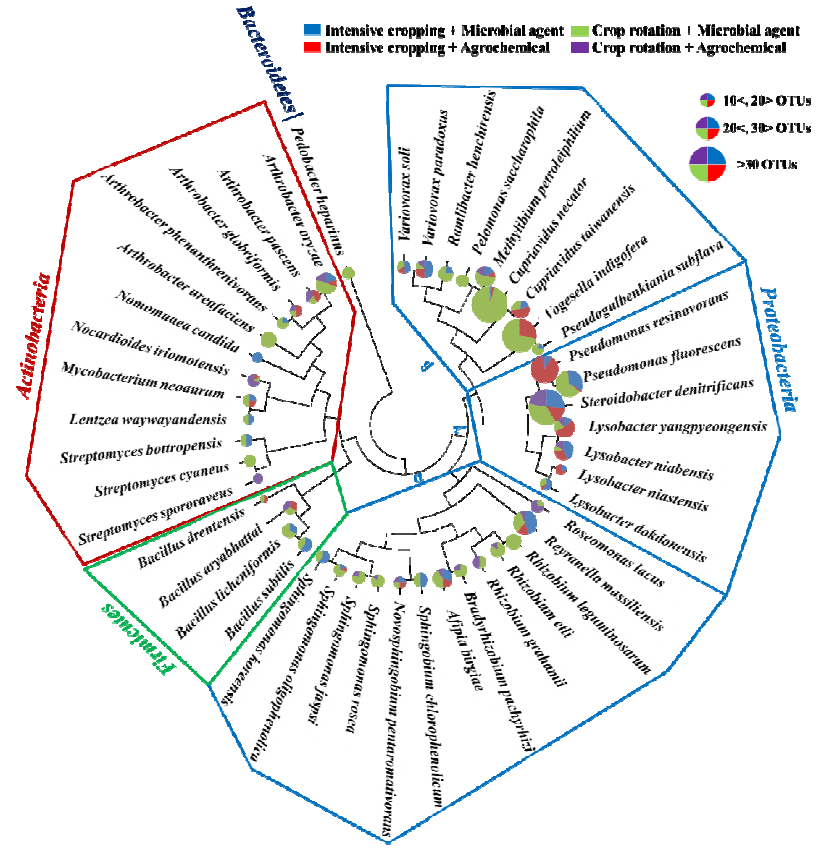

Fig. 3: Phylogenetic tree of classifiable bacterial species that existed in more than 10 operational taxonomic units (OTUs), constructed by using pyrosequencing-derived data. Large circles indicate $>30$ OTUs; medium-sized circles indicate 20-30 OTUs; small circles indicate 10-20 OTUs; blue circle, intensive cropping sample treated with a microbial consortium; red circle, intensive cropping sample treated with an agrochemical; green circle, crop rotation sample treated with a microbial consortium; violet circle, crop rotation sample treated with an agrochemical

and microbial agent treatment (Table 2). This result confirms that there is a relation between a high red pepper yield and high bacterial diversity in red pepper field soil. Therefore, the strains in the microbial agent (Bacillus subtilis $\mathrm{AH} 18$, B. licheniformis $\mathrm{K} 11$, and Pseudomonas fluorescens 2112) had a positive effect, not only on red pepper yield, but also on growth promotion (Fig. 1 and 4). 

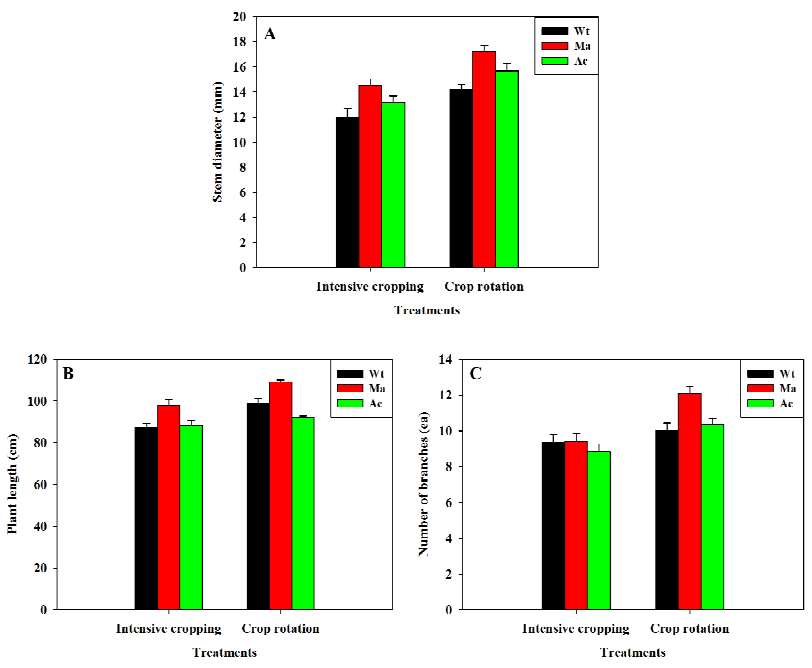

Fig. 4: Growth parameters of red pepper plants grown for six months in the experimental field. A, stem diameter; B, plant length; $\mathrm{C}$, number of branches. Values are expressed as the mean $\pm S D \quad(n=6)$ from the six independent experiments. $\mathrm{Wt}$, only water treatment; Ma, microbial agent treatment; Ac, agrochemical treatment



Fig. 5: Relative abundance of vesicular-arbuscular mycorrhizal (VAM) fungi using total phospholipid fatty acid extracted in the red pepper experimental field applying the intensive cropping and crop rotation. Values are expressed as the mean $\pm S D(n=6)$ from the six independent experiments. $\mathrm{Np}$, non-planting; $\mathrm{Wt}$, only water treatment; Ma, microbial agent treatment; Ac, agrochemical treatment

Khalid et al. (2004) reported that fluorescent Pseudomonads and species of Bacillus have a very high efficiency in plant root colonization and the production of phytohormones, resulting in improved crop yield.

Bradyrhizobium and Rhizobium species are symbiotic partners that form nitrogen-fixing nodules on legumes. These bacteria share the same characteristics as PGPR, which can produce phytohormones, siderophores, and convert the insoluble form of phosphorus to a soluble form through the acidification and secretion of organic acid (Lugtenberg et al., 2002; Richardson et al., 2009). Antoun et al. (1998) investigated Rhizobium and Bradyrhizobium species on non-legumes, such as radishes, and found that these bacteria produced indole-3-acetic acid (IAA), solubilized phosphorus, and increased radish dry matter yield (Antoun et al., 1998). Interestingly, we found that Bradyrhizobium and Rhizobium species belonging to $\alpha$ proteobacteria existed only in the crop rotation soils (Fig. 4). When Rhizobium spp. were present in the soil, Xie et al. (1995) found that the colonization of vascular arbuscular mycorrhizal (VAM) fungi increased, due to an increase in lipo-oligosaccharide signal molecules concentration which involved in the symbiosis (Xie et al., 1995). Our results are also in agreement, while using phospholipid fatty acid (PLFA) analysis (Fig. 5) that VAM fungi increased in the crop rotation field than those of continuous crop field. To the best of our knowledge, this work is the first to demonstrate that both crop rotation and microbial agent treatment have an effect upon both the bacterial community and the crop yield of red peppers.

In conclusion, crop rotation with kidney beans, and the application of a microbial agent, has a synergistic, positive effect, not only on rhizospheric soil bacterial community structure, but also on red pepper yield. Therefore, ecofriendly farming methods, such as crop rotation and microbial agent use, are essential for sustainable agricultural development.

\section{Acknowledgements}

This study was supported by the Basic Science Research Program of the National Research Foundation of Korea (NRF), funded by the Ministry of Education, Science, and Technology (NRF-2012-0001795), and the Cooperative Research Program for Agriculture Science and Technology Development (Project No. PJ008965), Rural Development Administration, Republic of Korea.

\section{References}

Acosta-Martínez, V., S. Dowd, Y. Sun and V. Allen, 2008. Tag-encoded pyrosequencing analysis of bacterial diversity in a single soil type as affected by management and land use. Soil Biol. Biochem., 40: 2762-2770

Ahmad, M., D. Moon, K. Lim, C. Shope, S. Lee, A.A. Usman, K.R. Kim, J.H. Park, S.O. Hur, J. Yang and Y. Ok, 2012. An assessment of the utilization of waste resources for the immobilization of $\mathrm{Pb}$ and $\mathrm{Cu}$ in the soil from a Korean military shooting range. Environ. Earth Sci., 67: 1023-1031

Antoun, H., C. Beauchamp, N. Goussard, R. Chabot and R. Lalande, 1998. Potential of Rhizobium and Bradyrhizobium species as plant growth promoting rhizobacteria on non-legumes: Effect on radishes (Raphanus sativus L.). Plant Soil, 204: 57-67

Berg, G., S. Kurze, A. Buchner, E.M. Wellington and K. Smalla, 2000 Successful strategy for the selection of new strawberry-associated rhizobacteria antagonistic to Verticillium wilt. Can. J. Microbiol., 46: 1128-1137 
Chun, J., K.Y. Kim, J.H. Lee and Y. Choi, 2010. The analysis of oral microbial communities of wild-type and toll-like receptor 2-deficient mice using a 454 GS FLX Titanium pyrosequencer. BMC Microbiol., 10: $101-108$

Chun, J., J.H. Lee, Y. Jung, M. Kim, S. Kim, B.K. Kim and Y.W. Lim, 2007. EzTaxon: a web-based tool for the identification of prokaryotes based on $16 \mathrm{~S}$ ribosomal RNA gene sequences. Int. J. Syst. Evol. Microbiol., 57: 2259-2261

Chung, S., H. Kong, J.S. Buyer, D.K. Lakshman, J. Lydon, S.D. Kim and D.P. Roberts, 2008. Isolation and partial characterization of Bacillus subtilis ME488 for suppression of soilborne pathogens of cucumber and pepper. Appl. Microbiol. Biotechnol., 80: 115-123

Cole, J.R., Q. Wang, E. Cardenas, J. Fish, B. Chai, R.J. Farris, A.S. KulamSyed-Mohideen, D.M. McGarrell, T. Marsh, G.M. Garrity and J.M. Tiedje, 2009. The Ribosomal Database Project: improved alignments and new tools for rRNA analysis. Nucleic Acids Res., 37: 141-145

Costa, R., M. Gotz, N. Mrotzek, J. Lottmann, G. Berg and K. Smalla, 2006. Effects of site and plant species on rhizosphere community structure as revealed by molecular analysis of microbial guilds. FEMS Microbiol. Ecol., 56: 236-249

Jeun, Y.C., K.S. Park, C.H. Kim, W.D. Fowler and J.W. Kloepper, 2004. Cytological observations of cucumber plants during induced resistance elicited by rhizobacteria. Biol. Cont., 29: 34-42

Jo, I.S. and M.H. Koh, 2004. Chemical changes in agricultural soils of Korea: data review and suggested countermeasures. Environ. Geochem. Health, 26: 105-117

Joo, GJ., 2005. Production of an anti-fungal substance for biological control of Phytophthora capsici causing phytophthora blight in red-peppers by Streptomyces halstedii. Biotechnol. Lett., 27: 201-205

Khalid, A., M. Arshad and Z.A. Zahir, 2004. Screening plant growthpromoting rhizobacteria for improving growth and yield of wheat. $J$. Appl. Microbiol., 96: 473-480

Kim, J.S., G. Sparovek, R.M. Longo, W.J. De Melo and D. Crowley, 2007. Bacterial diversity of terra preta and pristine forest soil from the Western Amazon. Soil Biol. Biochem., 39: 684-690

Kim, S., K.W. Lee, J. Park, H.J. Lee and I.K. Hwang, 2006. Effect of drying in antioxidant activity and changes of ascorbic acid and colour by different drying and storage in Korean red pepper (Capsicum annuит, L.). Int. J. Food Sci. Technol., 41: 90-95

Kim, S.D., L. Fuente Lde, D.M. Weller and L.S. Thomashow, 2012. Colonizing ability of Pseudomonasfluorescens 2112 , among collections of 2,4-diacetylphloroglucinol-producing Pseudomonas fluorescens spp. in pea rhizosphere. J. Microbiol. Biotechnol., 22: 763-770

Kloepper, J., A. Gutiérrez-Estrada and J. McInroy, 2007. Photoperiod regulates elicitation of growth promotion but not induced resistance by plant growth-promoting rhizobacteria. Can. J. Microbiol., 53: 159-167

Larkin, R.P. and C.W. Honeycutt, 2006. Effects of different 3-year cropping systems on soil microbial communities and rhizoctonia diseases of potato. Phytopathology, 96: 68-79

Lee, K., S. Kamala-Kannan, H. Sub, C. Seong and G. Lee, 2008. Biological control of Phytophthora blight in red pepper (Capsicum annuиm L.) using Bacillus subtilis. World J. Microbiol. Biotechnol., 24: $1139-1145$

Lee, S.H., C.G. Kim and H. Kang, 2011. Temporal dynamics of bacterial and fungal communities in a genetically modified (GM) rice ecosystem. Microb. Ecol., 61: 646-659

Lim, J.H. and S.D. Kim, 2009. Synergistic plant growth promotion by the indigenous auxins-producing PGPR Bacillus subtilis AH18 and Bacillus licheniforims K11. J. Kor. Soc. Appl. Biol. Chem., 52: 531-538
Lugtenberg, B. J., T.F. Chin-A-Woeng and G.V. Bloemberg, 2002. Microbeplant interactions: principles and mechanisms. Antonie Van Leeuwenhoek, 81: 373-383

Mayak, S., T. Tirosh and B.R. Glick, 2004. Plant growth-promoting bacteria that confer resistance to water stress in tomatoes and peppers. Plant Sci., 166: 525-530

Mendes, R., M. Kruijt, I. de Bruijn, E. Dekkers, M. van der Voort, J.H. Schneider, Y.M. Piceno, T.Z. DeSantis, G.L. Andersen, P.A. Bakker and J.M. Raaijmakers, 2011. Deciphering the rhizosphere microbiome for disease-suppressive bacteria. Science, 332: $1097-1100$

Peiffer, J.A., A. Spor, O. Koren, Z. Jin, S.G. Tringe, J.L. Dangl, E.S. Buckler and R.E. Ley, 2013. Diversity and heritability of the maize rhizosphere microbiome under field conditions. Proc. Natl. Acad. Sci. USA, 110: 6548-6553

Picard, C., F. Di Cello, M. Ventura, R. Fani and A. Guckert, 2000. Frequency and biodiversity of 2,4-diacetylphloroglucinol-producing bacteria isolated from the maize rhizosphere at different stages of plant growth. Appl. Environ. Microbiol., 66: 948-955

Qiu, M., R. Zhang, C. Xue, S. Zhang, S. Li, N. Zhang and Q. Shen, 2012. Application of bio-organic fertilizer can control Fusarium wilt of cucumber plants by regulating microbial community of rhizosphere soil. Biol. Fert. Soils, 48: 807-816

Raaijmakers, J.M., D.M. Weller and L.S. Thomashow, 1997. Frequency of antibiotic-producing Pseudomonas spp. in natural environments. Appl. Environ. Microbiol., 63: 881-887

Rajkumar, M., W.H. Lee and K.J. Lee, 2005. Screening of bacterial antagonists for biological control of Phytophthora blight of pepper. $J$ Basic. Microbiol., 45: 55-63

Richardson, A.E., J.M. Barea, A.M. McNeill and C. Prigent-Combaret, 2009. Acquisition of phosphorus and nitrogen in the rhizosphere and plant growth promotion by microorganisms. Plant Soil, 321: 305-339

Smith, GBB. and J.M. Tiedje, 1992. Isolation and characterization of a nitrite reductase gene and its use as a probe for denitrifying bacteria. Appl. Environ. Microbiol., 58: 376-384

Sørensen, J., 1997. The rhizosphere as a habitat for soil microorganisms. In: Modern Soil Microbiology. pp: 21-45. J.D. van Elsas, J.T. Trevors and E.M.H. Wellington (eds.). Marcel Dekker, New York, USA

Teixeira, L.C., R.S. Peixoto, J.C. Cury, W.J. Sul, V.H. Pellizari, J. Tiedje and A.S. Rosado, 2010. Bacterial diversity in rhizosphere soil from Antarctic vascular plants of Admiralty Bay, maritime Antarctica. ISME J., 4: 989-1001

Wommack, K.E., J. Bhavsar and J. Ravel, 2008. Metagenomics: read length matters. Appl. Environ. Microbiol., 74: 1453-1463

Xie, Z.P., C. Staehelin, H. Vierheilig, A. Wiemken, S. Jabbouri, W.J. Broughton, R. Vogeli-Lange and T. Boller, 1995. Rhizobial nodulation factors stimulate mycorrhizal colonization of nodulating and nonnodulating soybeans. Plant Physiol., 108: 1519-1525

Xuan, D., V. Guong, A. Rosling, S. Alström, B. Chai and N. Högberg, 2012. Different crop rotation systems as drivers of change in soil bacterial community structure and yield of rice, Oryza sativa. Biol. Fert. Soils, 48: $217-225$

Yildirim, E., H. Karlidag, M. Turan and M. Donmez. 2010. Potential use of plant growth promoting rhizobacteria in organic broccoli (Brassica oleracea $\mathrm{L}$., var. italica) production. In: Ecofruit $14^{\text {th }}$ International Conference on Organic Fruit-Growing. Proceedings for the Conference, Hohenheim, Germany, pp: 227-235. 22-24 February 2010. Fördergemeinschaft Ökologischer Obstbau eV (FÖKO)

(Received 23 June 2014; Accepted 20 October 2014) 